\title{
Penegakan Hukum terhadap Penangkapan Ikan secara Ilegal yang Melibatkan Negara Lain
}

\author{
Merisa Nur Putri \\ Fakultas Hukum, Universitas Kuningan, Indonesia \\ E-mail : merisanurputri@gmail.com
}

\begin{abstract}
The purpose of this study is to study the juridical discussion about fish theft carried out in other countries in Indonesia, the impact of fish safety in Indonesia and the penalties received by fish theft in Indonesia. Type of descriptive research analysis by discussing juridical normative. The results of the study revealed the facts before improvements in various fields of government were not confirmed in court preparations. The impact of illegal fishing is Damaging the Preservation of Fish in the Indonesian Sea, Harming the National Economy, Environmental Damage, Illegal Fisheries Violating Indonesian Sovereignty. Related to Sanctions Against Foreign Fishing Vessels is the application of Criminal Penalties for Fisheries, and Drowning of Foreign Fish Ships conducting Illegal Fishing at ZEEI. In conclusion now law enforcement against illegal fishing has begun in the follow-up by the Indonesian government by converting Article 69 paragraph (4) of Law Number 45 of 2009 concerning Fisheries.
\end{abstract}

Keywords: Law Enforcement, Illegal Fisshing

\begin{abstract}
Abstrak
Tujuan penelitian ini adalah untuk mengetahui tinjauan yuridis mengenai pencurian ikan yang dilakukan negeri lain di Indonesia, dampak yang ditimbulkan dari adanya pencurian ikan di Indonesia dan sanksi yang akan diterima oleh pencurian ikan di Indonesia. Jenis peneltian deskriptif anlisis dengan pendekatan yuridis normatif. Hasil penelitian mengemukakan bahwa sebelum adanya perbaikan diberbagai bidang kelautan pemerintah tidak tegas dalam memproses pelaku pelanggaran. Dampak dari ilegal fishing adalah Merusak Kelestarian Ikan di Laut Indonesia, Merugikan Ekonomi Negara, Kerusakan Lingkungan, Illegal Fishing Melanggar Kedaulatan Indonesia. Adapun Sanksi Terhadap Kapal Ikan Asing yaitu penerapan Hukuman Pidana Perikanan, dan Penenggelaman Kapal Ikan Asing yang melakukan Illegal Fishing di ZEEI. Kesimpulannya sekarang penegakan hukum terhadap pelaku illegal fishing sudah mulai di tindak tegas oleh pemerintah Indonesia dengan menjalankan fungsi Pasal 69 ayat (4) Undang-Undang Nomor 45 Tahun 2009 tentang Perikanan.
\end{abstract}

Kata kunci: Penegakan Hukum, Illegal Fisshing

\section{PENDAHULUAN}

Sebagai negara kepulauan yang sebagian besar wilayahnya terdiri dari laut, Indonesia memiliki potensi perikanan yang sangat besar dan beragam. Potensi perikanan yang dimiliki merupakan potensi ekonomi yang dapat dimanfaatkan untuk masa depan bangsa, sebagai salah satu tulang punggung pembangunan nasional. Pemanfaatan secara optimal diarahkan pada pendayagunaan sumber daya ikan dengan memperhatikan daya dukung yang ada dan kelestariaanya untuk meningkatkan kesejahteraan rakyat, meningkatkan taraf hidup nelayan kecil dan pembudidaya ikan kecil, meningkatkan penerimaan dari devisa negara, menyediakan perluasan dan kesempatan kerja, meningkatkan produktivitas, nilai tambah dan daya saing hasil perikanan serta menjamin kelestarian sumber daya ikan, lahan pembudidayaan ikan serta tata ruang. Hal ini berarti bahwa pemanfaatan sumber daya perikanan harus seimbang dengan daya dukungnya, sehingga diharapkan dapat memberikan manfaat secara terus menerus. Salah satunya dilakukan dengan pengendalian usaha perikanan melalui pengaturan pengelolaan perikanan.

Konvensi Perserikatan Bangsa-Bangsa mengenai Hukum Laut Tahun 1982 yang telah diratifikasi dengan Undang-Undang Nomor 17 Tahun 1985 tentang Pengesahan United Nations Convention on the Law of the Sea 1982, menempatkan Indonesia memiliki hak 
berdaulat (sovereign rights) untuk melakukan pemanfaatan, konservasi, dan pengelolaan sumber daya ikan di Zona Ekonomi Eksklusif (ZEE) Indonesia, dan Laut Lepas yang dilaksanakan berdasarkan persyaratan atau standar internasional yang berlaku. Oleh karena itu, dibutuhkan dasar hukum pengelolaan sumber daya ikan yang mampu menampung semua aspek pengelolaan sumber daya ikan dan mengantisipasi perkembangan kebutuhan hukum dan teknologi. Kehadiran Undang-Undang Nomor 31 Tahun 2004 tentang Perikanan diharapkan dapat mengantisipasi sekaligus sebagai solusi terhadap perubahan yang sangat besar di bidang perikanan, baik yang berkaitan dengan ketersediaan sumber daya ikan, kelestarian lingkungan sumber daya ikan, maupun perkembangan metode pengelolaan perikanan yang semakin efektif, efisien, dan modern.

Di sisi lain, terdapat beberapa isu dalam pembangunan perikanan yang perlu mendapatkan perhatian dari semua pihak, baik pemerintah, masyarakat maupun pihak lain yang terkait dengan pembangunan perikanan. Isu-isu tersebut diantaranya adanya gejala penangkapan ikan yang berlebih, pencurian ikan, dan tindakan illegal fishing lainnya yang tidak hanya menimbulkan kerugian bagi negara, tetapi juga mengancam kepentingan nelayan dan pembudi daya-ikan, iklim industri, dan usaha perikanan nasional. Permasalahan tersebut harus diselesaikan dengan sungguh-sungguh, sehingga penegakan hukum di bidang perikanan menjadi sangat penting dan strategis dalam rangka menunjang pembangunan perikanan secara terkendali dan berkelanjutan. Adanya kepastian hukum merupakan suatu kondisi yang mutlak diperlukan dalam penanganan tindak pidana di bidang perikanan. ${ }^{1}$ Selain itu Penegakan hukum merupakan isu yang menarik untuk diteliti karena berkaitan dengan implementasi peraturan perundang-undangan yang berlaku. ${ }^{2}$

Dalam Pasal 33 UUD RI 1945 tercantum dasar demokrasi ekonomi, produksi dikerjakan oleh semua, untuk semua dibawah pimpinan anggota-anggota masyarakat. Kemakmuran masyarakatlah yang diutamakan, bukan kemakmuran seorang saja. Selanjutnya dikatakan bahwa "Bumi dan air dan kekayaan alam yang terkandung dalam bumi adalah pokok-pokok kemakmuran rakyat. ${ }^{3}$ Konvensi Perserikatan Bangsa-Bangsa Tentang Hukum Laut Tahun 1982 yang telah diratifikasi dengan Undang-Undang Nomor 17 Tahun 1985 Tentang Pengesahan United Nations Convention On the Law of the Sea 1982, menempatkan Indonesia memiliki hak berdaulat untuk melakukan pemanfaatan, konservasi, dan pengelolaan sumber daya ikan di Zona Ekonomi Eksklusif (ZEE) Indonesia dan laut lepas. ${ }^{4}$ Kehadiran Undang-Undang Nomor 45 Tahun 2009 Tentang Perikanan diharapkan dapat mengantisipasi sekaligus sebagai solusi terhadap perubahan yang sangat besar dibidang perikanan, baik yang berkaitan dengan ketersediaan sumber daya ikan, kelestarian lingkungan sumber daya ikan, maupun perkembangan pengelolaan perikanan yang semakin efektif, efisien, dan modern.

Disisi lain, terdapat beberapa isu dalam pembangunan perikanan yang perlu mendapatkan perhatian dari semua pihak, baik pemerintah, masyarakat maupun pihak lain yang terkait dengan pembangunan perikanan. Isu-isu tersebut diantaranya adanya gejala penangkapan ikan yang berlebih, pencurian ikan, dan tindakan illegal fishing lainnya yang

\footnotetext{
${ }^{1}$ Djoko Tribawono, Hukum Perikanan Indonesia (Bandung : Pt Citra Aditya Bakti, 2013), Hlm. 13

${ }^{2}$ Suwari Akhmaddhian, Implementasi Penegakan Hukum Lingkungan Pada Sektor Pertambangan Di Kabupaten Kuningan, Jurnal Unifikasi, Issn 2354-5976 Vol. 04 Nomor o1 Januari 2017, hlm. 44

${ }^{3}$ Republik Indonesia, UUD 1945, Pasal 33.

${ }^{4}$ Djoko Tribawono. Op.Cit. Hlm. 14
} 
tidak hanya menimbulkan kerugian bagi negara, tetapi juga mengancam kepentingan nelayan dan pembudidaya ikan, iklim industri dan usaha perikanan nasional. Permasalahan tersebut harus diselesaikan dengan sungguh-sungguh, sehingga peneggakkan hukum dibidang perikanan menjadi sangat penting dan strategis dalam rangka menunjang pembangunan perikanan secara terkendali dan berkelanjutan. ${ }^{5}$

Sejak zaman dahulu kata sumber daya ikan sudah banyak dimanfaatkan manusia dan ini berlangsung terus hingga sekarang. Diawali dengan cara "berburu" menangkap/mencari ikan, manusia mendapatkannya dan memprioritaskan untuk santapan keluarga. Kemudian berkembangnya cara-cara membudidayakan ikan, yang muncul setelah manusia berfikir bahwa pada saatnya nanti bisa saja "kehabisan ikan" yang terjadi kalau terus menerus ditangkap tanpa memikirkan bagaimana "membuat" anak-anaknya. Karena semakin banyak manusia yang butuh makan, termasuk mengkonsumsi ikan, maka pemanfaatan sumber daya yang semula hanya kebutuhan keluarga, berubah menjadi bentuk yang bersifat komersial. ${ }^{6}$

Pada abad modern ini pengelolaan dan penangkapan ikan dilengkapi dengan peralatan yang cukup modern, tidak lagi penangkapan yang dilakukan secara tradisional. Namun dampak yang cukup dirasakan dari kegiatan pengelolaan tersebut adalah pengaruhnya terhadap ekosistem/lingkungan laut, terutama apabila pengelolaannya tanpa memperhatikan ketentuan dan persyaratan yang diwajibkan. Dalam penentuan persyaratan sudah diperhitungkan kapasistas dan kualitas lingkungan laut, sehingga pelanggaran terhadap persyaratan akan merusak atau menghancurkan lingkungan laut. ${ }^{7}$

Sejak terintegrasinya ekonomi Indonesia ke dalam sistem perekonomian internasional yang berorientasi pada modal atau capital, maka pemanfaatan sumber daya alam sebagai sumber penggerak kegiatan ekonomi menjadi tak terelakkan. Lingkungan hidup dalam pengertian ekologi tidak mengenal batas wilayah, tetapi yang dimaksud dengan lingkungan hidup Indonesia secara hukum mencakupi ruang tempat negara Indonesia melaksanakan kedaulatan dalam wilayah yurisdiksinya. ${ }^{8}$ Bagi kebanyakan masyarakat Indonesia yang awam akan arti pentingnya lingkungan hidup, maka di dalam pandangannya lingkungan hanyalah objek sederhana yang sekadar terkait dengan alam, tumbuhan, dan hewan. Padahal sesungguhnya, ruang lingkup lingkungan jauh lebih luas daripada hal tersebut, yaitu menyangkut entitas menyeluruh di mana semua makhluk hidup berada. Dalam konteks pembangunan negara dan pemberdayaan masyarakat, segala aktivitas dan kegiatannya tidak dapat mengenyampingkan eksistensi lingkungan pada titik dan batas tertentu. Oleh karenanya, pembangunan dan pemberdayaan yang tidak memberikan perhatian serius terhadap lingkungan justru akan menghasilkan antipembangunan dan anti-pemberdayaan. Terlebih lagi, perlindungan terhadap lingkungan juga terkait erat dengan pemenuhan hak asasi manusia. ${ }^{9}$ Dari latar beakang masalah tersebut, maka rumusan dalam penelitian ini adalah sebagai berikut: Bagaimana tinjauan

\footnotetext{
${ }^{5}$ Supriadi Dan Alimuddin, Hukum Perikanan Di Indonesia ( Jakarta: Sinar Grafika, 2011 ), Hlm. 521

${ }^{6}$ Djoko Tribawono, Op.cit. hlm.1

${ }^{7} J o k o$ Subagyo, Hukum Laut Indonesia (Jakarta: Pt Rineka Cipta, 1993), Hlm. 9

${ }^{8}$ Eko Handoyo, “Aspek Hukum Pengelolaan Lingkungan Hidup”, Jurnal Ilmu Hukum Pandecta, Vol. 3 No.2 JuliDesember 2009, Fakultas Hukum Universitas Negeri Semarang, hlm. 20

${ }^{9}$ Bridget Lewis, "Environmental Rights Or A Right To The Environment? Exploring The Nexus Between Human Rights And Environmental Protection”, Macquarie Journal Of International And Comparative Environmental Law, Vol. 8 No. 1, 2012, Hlm 36-47.
} 
yuridis mengenai pencurian ikan yang dilakukan negeri lain di Indonesia?, Bagaimana dampak yang ditimbulkan dari adanya pencurian ikan di Indonesia ? dan Bagaimana sanksi yang akan diterima oleh pencurian ikan di Indonesia?

\section{METODE PENELITIAN}

Penelitian ini dilakukan dengan menggunakan metode deskriptif-analistis, yaitu suatu metode dalam meneliti status sekelompok manusia, suatu obyek, suatu kondisi, suatu sistem pemikiran ataupun suatu peristiwa pada masa sekarang, ${ }^{10}$ Penelitian ini menggunakan pendekatan yuridis normatif, maksudnya adalah bahwa dalam menganalisis permasalahan dilakukan dengan cara memadukan bahan-bahan hukum dan studi kepustakaan.

\section{HASIL DAN PEMBAHASAN}

\section{A. Tinjauan Yuridis Mengenai Pencurian Ikan di Indonesia}

Tindakan menenggelamkan kapal illegal pada dasarnya bukan merupakan kebijakan baru bagi Pemerintah Indonesia, karena kebijakan ini pernah dilakukan pada masa pemerintahan Megawati Soekarnoputri. Seperti diketahui salah satu fungsi penerapan sanksi hukum adalah agar timbul efek jera pada pelaku pelanggaran atau kejahatan. Lemahnya penegakan hukum selama ini dan tidak adanya penindakan terhadap pelaku pelanggaran atau kejahatan terjadi karena tidak berorientasi kepada efek jera dapat dianggap sebagai kontribusi negara secara tidak langsung terhadap suburnya tindak pidana yang terjadi. Bahkan dapat dikatakan sebagai bentuk ketidakmampuan negara dalam memberikan perlindungan hukum kepada warganya, baik nelayan pada khususnya maupun rakyat Indonesia secara keseluruhan sebagai pemilik sumber daya laut Indonesia.

Dalam hukum, khususnya hokum pidana yang diatur adalah tentang perilaku yang harus ditaati oleh setiap subjek hukum, perbuatan mana yang boleh dilakukan dan perbuatan mana yang tidak boleh dilakukan. Perilaku yang tidak sesuai dengan norma/penyelewengan terhadap norma inilah yang dapat menimbulkan permasalahan di bidang hukum dan merugikan masyarakat. Penyelewengan yang demikian biasanya oleh masyarakat disebut sebagai suatu pelanggaran, bahkan sebagai suatu kejahatan. Oleh karena itu, terhadap kapal asing illegal yang melakukan pencurian ikan perlu diberi efek jera dengan cara menindak tegas pelaku sesuai dengan peraturan perundang-undangan yang berlaku. Tujuannya untuk menghindari kerugian masyarakat dan negara yang lebih besar.

Kebijakan penenggelaman kapal asing illegal diyakini tidak akan mempengaruhi hubungan bilateral, regional, dan multilateral Indonesia dengan negara lain. Menurut Guru Besar Hukum Internasional Universitas Indonesia, Hikmahanto Juwana, terdapat lima alasan kenapa kebijakan tersebut justru layak didukung dan tidak akan memperburuk hubungan antarnegara. Pertama, tidak ada negara di dunia ini yang membenarkan tindakan warganya yang melakukan kejahatan di negara lain. Kapal asing yang ditenggelamkan merupakan kapal yang tidak berizin untuk menangkap ikan di wilayah Indonesia, sehingga disebut tindakan kriminal. Kedua, tindakan penenggelaman dilakukan di wilayah kedaulatan dan hak berdaulat Indonesia (zona ekonomi eksklusif). Ketiga, tindakan penenggelaman dilakukan atas dasar ketentuan hukum yang sah, yaitu Pasal 69 ayat (4) UU

\footnotetext{
${ }^{10}$ Hadari Nawawi, Metode Penelitian Bidang Sosial, Gajah Mada University Press, Yogyakarta, 2005, hal. 33.
} 
Perikanan. Keempat, negara lain harus memahami bahwa Indonesia dirugikan dengan tindakan kriminal tersebut jika terus dibiarkan. ${ }^{11}$

Namun demikian, pemerintah perlu mensosialisasikan kebijakan tersebut kepada negara-negara lain. Hikmahanto Juwana menegaskan mekanisme yang dapat dilakukan pemerintah adalah menginformasikan kebijakan tersebut kepada para duta besar yang bertugas di Indonesia untuk meneruskannya kepada pemerintah masing-masing, terutama kepada negara-negara yang kapalnya kerap memasuki wilayah Indonesia secara ilegal, seperti Thailand, Filipina, Malaysia, Tiongkok, dan juga perwakilan Taiwan. Langkah selanjutnya, Pemerintah berkoordinasi dengan perwakilan negara yang kapalnya ditenggelamkan. Dengan demikian, hubungan baik antar negara diharapkan tetap terjaga.

Illegal Fishing telah diatur oleh Undang-Undang Nomor 31 Tahun 2004 tentang perikanan agar sumber daya ikan tetap lestari serta pemanfaatannya dapat optimal dan berkelanjutan. Pasal 8 ayat 1,2, dan 3, Pasal 9 dan Pasal 12 ayat 1 Undang-Undang Nomor 31 Tahun 2004 tentang perikanan mengatur tentang larangan terhadap penggunaan bahan peledak, bahan beracun dan aliran listrik. Pasal 1 ayat 5 dalam Undang-Undang Nomor 45 Tahun 2009 tentang perubahan atas Undang-Undang Nomor 31 Tahun 2004 tentang perikanan adalah : "Penangkapan ikan adalah kegiatan untuk memperoleh ikan diperairan yang tidak termasuk dalam keadaan dibudidayakan dengan alat atau cara apapun, termasuk kegiatan yang menggunakan kapal untuk memuat, mengangkut, menyimpan, mendinginkan, menangani, mengelola, dan/atau mengawetkan".

Dalam hukum pidana terdapat asas lex specialis derogate legi generalis, yang berarti peraturan yang khusus mengesampingkan peraturan yang umum. Maksudnya apabila undang-undang telah mengatur tentang suatu tindak pidana maka tidak perlu menggunakan aturan yang ada dalam KUHP. Sehingga dalam perkara tentang penangkapan ikan dengan menggunakan bom atau bahan peledak aturan yang digunakan hendaknya undang-undang yang ada yaitu Undang-Undang Nomor 45 Tahun 2009 tentang Perikanan. Tindak pidana perikanan juga dapat didefenisikan dari beberapa aspek yaitu :

1. Pengertian tindak pidana di bidang perikanan diartikan dari aspek ruang lingkup aktivitas di bidang perikanan;

2. Pengertian tindak pidana di bidang perikanan yang diberikan atas dasar modus operandi tindak pidana yang dilakukan;

3. Pengertian tindak pidana perikanan dilihat dari aspek wilayah atau daerah atau tempat terjadinya tindak pidana, maka tindak pidana di bidang perikanan dapat diartikan sebagai tindak pidana yang merupakan bagian dari tindak pidana wilayah perairan.

Penangkapan ikan dengan menggunakan bom/bahan peledak yang digunakan oleh pelaku tindak pidana atau kejahatan dengan maksud dan tujuan tertentu, dengan cara atau modus kejahatan yang telah direncanakan sehingga menyebabkan rusaknya potensi sumber daya ikan di wilayah pengelolaan perikanan Negara Republik Indonesia merupakan perbuatan yang dilarang oleh peraturan perundang-undangan sehingga digolongkan dalam tindak pidana perikanan. Pasal 85 Undang-Undang Nomor 45 Tahun 2009 tentang tindak perikanan mengatur tentang penangkapan ikan dengan menggunakan bom/bahan peledak berbunyi : "Setiap orang yang dengan sengaja memiliki, menguasai, membawa, dan/atau

${ }^{11}$ Sulasi Rohingati, Penenggelaman Kapal Ikan Asing: Upaya Penegakan Hukum Laut Indonesia, Jurnal Info Singkat Hukum, Vol. VI, No. 24/II/P3DI/Desember/2014, hlm. 3. 
menggunakan alat penangkapan ikan yang mengganggu dan merusak keberlanjutan sumber daya ikan di kapal penangkap ikan di wilayah pengelolaan perikanan Negara Republik Indonesia sebagaimana dimaksud dalam Pasal 9 dipidana dengan penjara paling lama 5 (lima) tahun dan denda paling banyak Rp.2.00o.ooo.ooo,oo (dua miliar rupiah)"

Dalam pasal diatas menyebutkan ancaman pidana bagi pelaku dengan ancaman pidana paling lama 5 (lima) tahun dan denda paling banyak Rp.2.00o.ooo.ooo,oo (dua miliar rupiah). Di dalam UNCLOS 1982 disebutkan hak dan yurisdiksi negara pantai di ZEE meliputi:

1. Eksplorasi dan eksploitasi sumber daya kelautan (hayati-non hayati);

2. Membuat dan memberlakukan peraturan perundang-undangan yang berkaitan dengan eksplorasi dan eksploitasi sumber daya kelautan;

3. Pembangunan pulau buatan dan instalasi permanen lainnya;

4. Mengadakan penelitian ilmiah kelautan; dan

5. Perlindungan lingkungan laut.

Sedangkan kewajiban negara pantai terkait dengan Zona Economi Eklusif yaitu meliputi antara lain:

1. Menghormati eksistensi hak dan kewajiban negara lain atas wilayah ZEE;

2. Menentukan maximum allowable catch (tangkapan maksimum yang diijinkan) untuk sumber daya hayati dalam hal ini perikanan; dan

3. Dalam hal negara pantai tidak mampu memanen keseluruhan allowable catch (tangkapan yang diijinkan), memberikan akses kepada negara lain atas surplus allowable catch (surplus tangkapan yang diijinkan) melalui perjanjian sebelumnya untuk optimalisasi pemanfaatan sumber daya kelautan terutama sumber daya perikanan dengan tujuan konservasi.

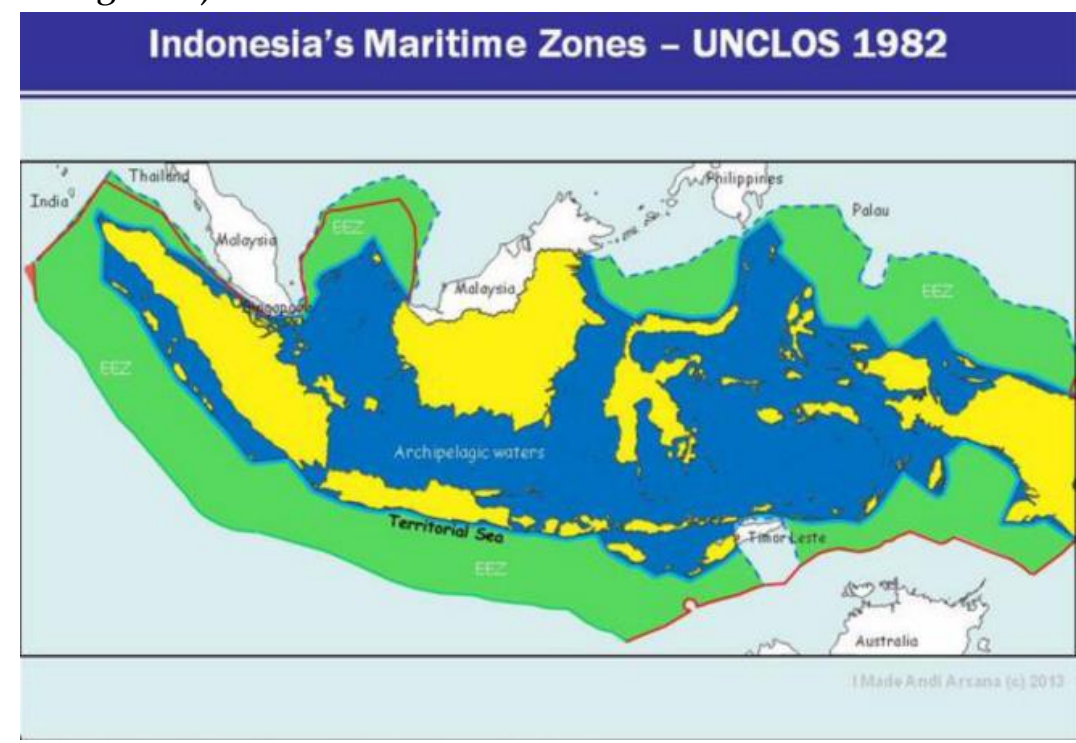

Gambar 1.1 Zona Maritim Indonesia-UNCLOS 1982

Penegakkan hukum terhadap tindak pidana illegal fishing di Indonesia antara lain sebagai berikut :

1. Undang-Undang Nomor 31 Tahun 2004 dan perubahannya Undang-Undang Nomor 45 Tahun 2009 tentang Perikanan. 
2. Undang-Undang Nomor 27 Tahun 2007 tentang Pengelolaan Wilayah Pesisir dan PulauPulau Kecil serta aturan pelaksanaannya lainnya seperti : Peraturan Pemerintah Nomor 54 Tahun 2005 tentang Usaha Perikanan.

3. Peraturan Pemerintah Nomor 6o Tahun 2007 tentang Konservasi Sumber Daya Ikan.

4. Peraturan Pemerintah Nomor 30 Tahun 2008 tentang Penyelenggaraan Penelitian dan Pengembangan Perikanan.

5. Peraturan Menteri Kelautan dan Perikanan Nomor PER.13/MEN/2005 tentang Forum Koordinasi Penanganan Tindak Pidana di Bidang Perikanan.

6. Peraturan Menteri Kelautan dan Perikanan Nomor PER.14/MEN/2005 tentang Komisi Nasional Pengkajian Sumber Daya Ikan.

7. Peraturan Menteri Kelautan dan Perikanan Nomor PER.15/MEN/2005 tentang Penangkapan Ikan dan/atau Pembudidaya Ikan di Wilayah Pengelolaan Perikanan Republik Indonesia yang Bukan untuk Tujuan Komersial.

8. Peraturan Menteri Kelautan dan Perikanan Nomor PER.o5/MEN/20o8 tentang Usaha Perikanan Tangkap, Peraturan Menteri Kelautan dan Perikanan Nomor PER.o6/MEN/2008 tentang Penggunaan Pukat Hela di Perairan Kalimantan Timur Bagian Utara, Peraturan Menteri Kelautan dan Perikanan Nomor PER.o8/MEN/2008 tentang Penggunaan Alat Penangkap Ikan Jaring Ingsang (Gill Net) di Zona Ekonomi Eksklusif Indonesia (ZEEI).

Dari penjelasan diatas terdapat rincian dari tinjauan yuridis yang digunakan dalam pencurian ikan yang dilakukan negara lain yaitu:

\begin{tabular}{|c|c|}
\hline No & Peraturan Terkait Pencurian Ikan \\
\hline 1 & Undang-Undang Nomor 31 Tahun 2004 Tentang Perikanan \\
\hline 2 & $\begin{array}{l}\text { Undang-Undang Republik Indonesia Nomor } 45 \text { Tahun } 2009 \text { Tentang Perubahan Atas } \\
\text { Undang-Undang Nomor } 31 \text { Tahun } 2004 \text { Tentang Perikanan }\end{array}$ \\
\hline 3 & $\begin{array}{l}\text { Undang-Undang Nomor } 27 \text { Tahun } 2007 \text { tentang Pengelolaan Wilayah Pesisir dan } \\
\text { Pulau }\end{array}$ \\
\hline 4 & Peraturan Pemerintah Nomor 6o Tahun 2007 tentang Konservasi Sumber Daya Ikan \\
\hline 5 & $\begin{array}{l}\text { Peraturan Pemerintah Nomor } 30 \text { Tahun } 2008 \text { tentang Penyelenggaraan Penelitian dan } \\
\text { Pengembangan Perikanan }\end{array}$ \\
\hline 6 & $\begin{array}{l}\text { Peraturan Menteri Kelautan dan Perikanan Nomor PER.13/MEN/2005 tentang Forum } \\
\text { Koordinasi Penanganan Tindak Pidana di Bidang Perikanan }\end{array}$ \\
\hline 7 & $\begin{array}{l}\text { Peraturan Menteri Kelautan dan Perikanan Nomor PER.14/MEN/2005 tentang Komisi } \\
\text { Nasional Pengkajian Sumber Daya Ikan }\end{array}$ \\
\hline 8 & $\begin{array}{l}\text { Peraturan Menteri Kelautan dan Perikanan Nomor PER.15/MEN/2005 tentang } \\
\text { Penangkapan Ikan dan/atau Pembudidaya Ikan Di Wilayah Pengelolaan Perikanan } \\
\text { Republik Indonesia Yang Bukan Untuk Tujuan Komersial }\end{array}$ \\
\hline 9 & $\begin{array}{l}\text { Peraturan Menteri Kelautan dan Perikanan Nomor PER.o5/MEN/20o8 tentang Usaha } \\
\text { Perikanan Tangkap, Peraturan Menteri Kelautan dan Perikanan Nomor } \\
\text { PER.o6/MEN/20o8 tentang Penggunaan Pukat Hela di Perairan Kalimantan Timur } \\
\text { Bagian Utara, Peraturan Menteri Kelautan dan Perikanan Nomor PER.o8/MEN/20o8 } \\
\text { tentang Penggunaan Alat Penangkap Ikan Jaring Ingsang (Gill Net) di Zona Ekonomi } \\
\text { Eksklusif Indonesia (ZEEI) }\end{array}$ \\
\hline
\end{tabular}

Tabel 1.1 Peraturan Terkait Pencurian Ikan 


\section{B. Penegakan Hukum dalam Pencurian Ikan di Indonesia}

Maraknya kegiatan Illegal Unreported and Unregulated (IUU) Fishing yang terjadi di laut Indonesia semakin menghawatirkan, berdasarkan data yang dilansir Kementerian Kelautan dan Perikanan Republik Indonesia kerugian negara akibat illegal fishing mencapai 300 trilyun rupiah pertahun, yaitu dengan memperhitungkan tingkat kerugiannya yang mencapai $25 \% \mathrm{~d}$ ari total potensi perikanan Indonesia kerugian tersebut berdampak merugikan negara dan mengancam kelestarian sumber daya kelautan danperikanan. ${ }^{12}$

Setiap kejahatan tentunya menghasilkan kerugian yang berdampak pada semua sektor kehidupan, negara, masyarakat, dan lingkungan laut adalah korban langsung dari tindakan illegal fishing tersebut. Dampak kerugian inilah yang menjadi salah satu sebab utama suatu tindakan manusia bisa digolongkan terhadap kejahatan, illegal fishing dalam hal ini merupakan tindak kejahatan yang sudah nyata dan seharusnya ditindak tegas karena sudah memberikan kerugian yang sangat besar terhadap semua sektor kehidupan masyarakat Indonesia. ${ }^{13}$

1. Merusak Kelestarian Ikan di Laut Indonesia, Faktanya sekarang praktek perikanan yang tidak dilaporkan atau laporannya salah (misreported), laporan ikannya di bawah standar (underreported), dan praktek perikanan yang tidak diatur (unregulated) akan menimbulkan permasalahan yang sangat krusial bagi kelestarian ikan Indonesia yaitu masalah akurasi data tentang stok ikan yang tersedia. Jika data stok ikan tidak akurat, hampir dipastikan pengelolaan perikanan tidak akan tepat dan akan mengancam kelestarian stok ikan nasional dan global.

2. Merugikan Ekonomi Negara. Secara nasional negara adalah pihak yang dirugikan langsung oleh adanya kejahatan illegal fishing ini. Berdasarkan Laporan Badan Pemeriksa Keuangan (BPK) kerugian negara dari sektor kelautan dan perikanan diperkirakan kerugian negara dari IUU Fishing sebesar Rp 300 Triliun setiap Tahun.

3. Kerusakan Lingkungan, Dalam prakteknya para pelaku illegal fishing tak segan-segan menggunakan alat penangkapan ikan atau Fish Aggregating Devices (FAD) yang bisa merusak lingkungan laut (destruktif fishing), misalnya adalah penangkapan ikan yang menggunakan bom ikan, penggunaan racun sianida, pembiusan dan penggunaan alat tangkap ikan seperti trawl (pukat harimau), mereka tidak sadar bahwa penangkapan ikan dengan cara itu akan mengeksploitasi habitat laut sebagai tempat ikan-ikan hidup dan melakukan reproduksi.

4. Illegal Fishing Melanggar Kedaulatan Indonesia, Dari mayoritas kasus illegal fishing yang terjadi di Indonesia, pelanggaran kedaulatan negara Indonesia dilakukan oleh semua pelaku illegal fishing dari negara-negara tersebut diatas, para nelayan asing itu telah melanggar batas teritorial kedaulatan Indonesia tanpa izin, memasuki laut Indonesia dan merampok aset perikanan Indonesia. Sikap tegas aparat penegak hukum Indonesia harus ditegakan dalam menjaga kedaulatan Indonesia agar tidak dimasuki oleh negara-

\footnotetext{
${ }^{12}$ Kementerian Kelautan Dan Perikanan Republik Indonesia, Laporan Kementerian Kelautan Dan Perikanan Republik Indonesia Tahun 2014, (Jakarta: Sekretaris Jenderal Kkp Ri, 2014), Hlm. 18-20.

${ }^{13}$ Riza Damanik, Dkk. Menjala Ikan Terakhir (Sebuah Fakta Krisis Di Laut Indonesia), (Jakarta: Walhi, 20o8), Hlm. 33
} 
negara yang bermaksud merampok aset bangsa. Karena tindakan tersebut merupakan salah satu bentuk tindak pidana yang marak terjadi di perairan Indonesia. ${ }^{14}$

Pengaturan sanksi bagi pencuri ikan, penerapan sanksi terhadap kapal ikan asing di Indonesia yaitu :

a. Jenis dan Sifat Hukuman Pidana Perikanan

Jenis hukuman pidana pasal 1o KUHP dikenal terdapat dua jenis hukuman pidana, yaitu pidana pokok dan pidana tambahan.Pidana pokok merupakan hukuman yang wajib dijatuhkan hakim yang terdiri atas pidana mati, pidana penjara, pidana kurungan, dan pidana denda. ${ }^{15}$

b. Jenis Pelanggaran Pidana Perikanan

1) Tidak memiliki SIUP (Surat Ijin Usaha Perdagangan), dikenakan pasal 26 ayat (1) jo pasal 92 UU RI No. 31 Tahun 2004 Tentang Perikanan, dipidana dengan pidana penjara paling lama 8 (delapan) tahun dan denda paling banyak Rp. 1.500.00o.ooo,(satu miliyar lima ratur juta rupiah).

2) Alat penangkap ikan tidak sesuai dengan ukuran, dapat dikenakan pasal 85 UUP dengan pidana paling lama 5 (lima) tahun dan denda paling bayak Rp. 2.000.000.00o,- (dua miliar rupiah)

3) Tidak memiliki SIB, dikenakan pasal 98 Undang Undang Perikanan dengan dipidana penjara paling lama 1(satu) tahun dan denda paling banyak Rp. 200.000.000,- (dua ratus juta rupiah).

c. Sanksi Pidana Perikanan

Sanksi pidana menurut undang-undang perikanan bisa berupa sanksi administrasi (pencabutan ijin), kurungan badan (penjara) atau pun denda. Dan dengan sanksi tersebut dapat menimbulkan efek jera bagi pelaku illegal fishing di Zona Ekonomi Eksklusif Indonesia. Khusus dibidang perikanan yang ada didalam undang-undang ZEEI secara eksklusif sudah diatur didalam Undang-Undang Perikanan yang baru yaitu UU RI No. 34 tahun 2009 tentang perubahan UU RI No. 31 Tahun 2004 tentang Perikanan.

d. Penenggelaman Kapal Ikan Asing yang melakukan Illegal Fishing di ZEEI

Terdapat lima alasan kebijakan peneggelaman Kapal Ikan Asing layak didukung:

1) Tidak ada negara didunia ini yang membenarkan tindakan warganya yang melakukan kejahatan di negara lain, kapal asing yang ditenggelamkan merupakan kapal yang tidak memiliki izin untuk menangkap ikan di wilayah Indonesia. Hal itu dianggap tindakan kriminal. Artinya kapal yang ditenggelamkan sebelumnya telah melalui proses pengadilan dan telah berkekuatan hukum tetap bahwa yang bersangkutan bersalah.

2) Tindakan peneggelaman dilakukan diwilayah kedaulatan dan hak berdaulat Indonesia.

3) Tindakan penenggelaman dilakukan atas dasar payung hukum yang sah yaitu pasal 69 ayat (4) UUP 2009, sebelum tahun 2009 memang proses penenggelaman harus melalui putusan pengadilan yang berkekuatan hukum tetap.

\footnotetext{
${ }^{14}$ Abdul Qodir Jaelani Dan Udiyo Basuki, Illegal Unreported and Unregulated (IUU) Fishing: Upaya Mencegah dan Memberantas Illegal Fishing dalam Membangun Poros Maritim Indonesia, Jurnal Supremasi Hukum, Vol. 3, No. 1, Juni 2014, hlm. 180-181

${ }^{15}$ Gatot Supramono, Hukum Acara Pidana \& Hukum Pidana Di Bidang Perikanan, (Rineka Cipta, Jakarta, 2011), Hlm. 153.
} 
4) Negara lain harus memahami bahwa Indonesia dirugikan dengan tindakan kriminal tersebut. Jika terus dibiarkan maka kerugian yang dialami akan semakin besar.

5) Proses penenggelaman juga memperhatikan keselamatan dari para awak kapal. ${ }^{16}$

Ada dua cara penenggelaman kapal ikan asing yang dilakukan oleh pemerintah RI melalui Otoritas:

1. Penenggelaman kapal melalui putusan pengadilan

a. Otoritas yang menangkap kapal ikan asing membawa kapal dan ABK (Anak Buah Kapal) ke darat.

b. Di darat dimana ada pengadilan perikanan akan dilaksanakan proses hukum.

c. Setelah disidang dan divonis bersalah dan putusan mempunyai kekuatan hukum tetap kapal-kapal akan disita.

d. Bila kapal disita maka bergantung pada jaksa eksekutor akan melakukan apa terhadap kapal tersebut.

e. Apakah kapal akan di lelang atau dimusnakan, bila dimusnakan yang menjadi pilihan maka salah satu cara adalah diledakan dan ditenggelamkan.

2. Tertangkap tangan oleh otoritas

Cara kedua didasarkan pada pasal 69 Undang-Undang Perikanan Nomor 45 Tahun 2009. Pasal 69:

(1) Kapal pengawas perikanan berfungsi melaksanakan pengawasan dan penegakan hukum dibidang perikanan dalam wilayah pengelolaan perikanan Negara Republik Indonesia.

(2) Kapal pengawas perikanan sebagaimana dimaksud pada ayat (1), dapat dilengkapi dengan senjata api.

(3) Kapal pengawas perikanan dapat menghentikan, memeriksa, membawa dan menahan kapal yang diduga atau patut diduga melakukan pelanggaran diwilayah pengelolaan perikanan Negara Republik Indonesia ke pelabuhan terdekat untuk pemerosesanlebih lanjut.

(4) Dalam melaksanakan fungsi sebagaimana dimaksud ayat (1) penyidikdan/atau pengawas perikanan dapat melakukan tindakan khusus berupa pembakaran dan/atau penenggelaman kapal perikanan yang berbendera asing berdasarkan bukti permulaan yang cukup.

Pasal 93 Undang-Undang Perikanan Nomor 45 Tahun 2009. Yaitu :

(1) Setiap orang yang memiliki dan/atau mengoperasikan kapal penangkap ikan berbendera Indonesia melakukan penangkapan ikan di wilayah pengelolaan perikanan Negara Republik Indonesia dan/atau di laut lepas, yang tidak memiliki SIPI sebagaimana dimaksud dalam Pasal 27 ayat (1), dipidana dengan pidana penjara paling lama 6 (enam) tahun dan denda paling banyak Rp2.00o.00o.ooo,oo (dua miliar rupiah).

(2) Setiap orang yang memiliki dan/atau mengoperasikan kapal penangkap ikan berbendera asing melakukan penangkapan ikan di ZEEI yang tidak memiliki SIPI sebagaimana dimaksud dalam Pasal 27 ayat (2), dipidana dengan pidana penjara

\footnotetext{
${ }^{16}$ Gatot Supramono, Hukum Orang Asing Di Indonesia, (Sinar Grafika, Jakarta, 2012), Hal 108
} 
paling lama 6 (enam) tahun dan denda paling banyak Rp2o.0oo.ooo.ooo,oo (dua puluh miliar rupiah).

(3) Setiap orang yang mengoperasikan kapal penangkap ikan berbendera Indonesia di wilayah pengelolaan perikanan Negara Republik Indonesia, yang tidak membawa SIPI asli sebagaimana dimaksud dalam Pasal 27 ayat (3), dipidana dengan pidana penjara paling lama 6 (enam) tahun dan denda paling banyak Rp2.000.000.00o,oo (dua miliar rupiah).

(4) Setiap orang yang mengoperasikan kapal penangkap ikan berbendera asing di ZEEI, yang tidak membawa SIPI asli sebagaimana dimaksud dalam Pasal 27 ayat (3), dipidana dengan pidana penjara paling lama 6 (enam) tahun dan denda paling banyak Rp20.000.00o.ooo,oo (dua puluh miliar rupiah).

\section{SIMPULAN}

Illegal fishing adalah kegiatan penangkapan ikan secara illegal di perairan wilayah atau Zona Ekonomi Eksklusif (ZEE) suatu negara, artinya kegiatan penangkapan ikan yang tidak memiliki izin melakukan penangkapan ikan dari penangkapan ikan dari negara bersangkutan atau dengan kata lain pencurian ikan oleh pihak asing. Dalam hal penanganan kasus illegal fishing yang terjadi di wilayah perairan Indonesia, pemerintah terlalu lunak dalam memproses pelaku pelanggaran.

Hal inilah yang yang membuat negara-negara tetangga tidak segan terhadap Indonesia dan mengakibatkan kasus-kasus semacam ini selalu terjadi di Indonesia. Masalah tersebut bisa ditasi manakala pemerintah Indonesia melakukan perbaikan di berbagai bidang kelautan seperti pengadaan kapal-kapal petrol yang modern dan tindakan hukum yang jelas dan tegas khususnya penegakan pidana pada Undang-Undang Nomor 45 Tahun 2009 tentang Perikanan. Yang terbaru, Indonesia melalui Menteri Kelautan dan Perikanan telah mengeluarkan KEPMEN Nomor KEP/50/MEN/2012 tentang Rencana Aksi Nasional Pencegahan dan Penanggulangan Illegal, Ureported and Unregulated Fishing (IUU Fishing). Sekarang penegakan hukum terhadap pelaku illegal fishing sudah mulai di tindak tegas oleh pemerintah Indonesia dengan menjalankan fungsi Pasal 69 ayat (4) Undang-Undang Nomor 45 Tahun 2009 tentang Perikanan

\section{SARAN}

Pemerintah harus tegas dalam memproses pelaku pelanggaran, sehingga membuat negara-negara tetangga segan terhadap Indonesia dan dapat engurangi kasus-kasus terkait dengan pencurian hilang di Indonesia

\section{DAFTAR PUSTAKA}

Alimuddin, Supriadi Dan, Hukum Perikanan Di IndonesiaJakarta: Sinar Grafika, 2011.

Damanik, Riza, Dkk. Menjala Ikan Terakhir (Sebuah Fakta Krisis Di Laut Indonesia), Jakarta: Walhi, 2008.

Subagyo, Joko, Hukum Laut Indonesia, Jakarta: Pt Rineka Cipta, 1993.

Supramono, Gatot, Hukum Acara Pidana \& Hukum Pidana Di Bidang Perikanan, Rineka Cipta, Jakarta, 2011.

Supramono, Gatot, Hukum Orang Asing Di Indonesia, Sinar Grafika, Jakarta, 2012. 
Tribawono, Djoko, Hukum Perikanan Indonesia Bandung: PT Citra Aditya Bakti, 2013.

Handoyo, Eko, "Aspek Hukum Pengelolaan Lingkungan Hidup”, Jurnal Ilmu Hukum Pandecta, Vol. 3 No.2 Juli-Desember 2009, Fakultas Hukum Universitas Negeri Semarang.

Jaelani, Abdul Qodir Dan Udiyo Basuki, Illegal Unreported and Unregulated (IUU) Fishing: Upaya Mencegah dan Memberantas Illegal Fishing dalam Membangun Poros Maritim Indonesia, Jurnal Supremasi Hukum, Vol. 3, No. 1, Juni 2014.

Kementerian Kelautan Dan Perikanan Republik Indonesia, Laporan Kementerian Kelautan Dan Perikanan Republik Indonesia Tahun 2014, Jakarta: Sekretaris Jenderal Kkp RI, 2014 .

Lewis, Bridget, "Environmental Rights Or A Right To The Environment? Exploring The Nexus Between Human Rights And Environmental Protection”, Macquarie Journal Of International And Comparative Environmental Law, Vol. 8 No. 1, 2012.

Rohingati, Sulasi, Penenggelaman Kapal Ikan Asing: Upaya Penegakan Hukum Laut Indonesia, Jurnal Info Singkat Hukum, Vol. VI, No. 24/II/P3DI/Desember/2014.

Suwari Akhmaddhian, Implementasi Penegakan Hukum Lingkungan Pada Sektor Pertambangan Di Kabupaten Kuningan, Jurnal Unifikasi, Issn 2354-5976 Vol. 04 Nomor o1 Januari 2017 